\title{
Revision of Acroleptus Bourgeois, 1886 and Descriptions of New Acroleptina taxa (Coleoptera, Lycidae, Calopterini)
}

\section{Author: Vinicius S. Ferreira}

This is an Accepted Manuscript of an article published by Taylor \& Francis in 'Journal of Natural History' on 2019-12-10, available online: https://

www.tandfonline.com/10.1080/00222933.2020.1733120.

Ferreira, Vinicius S. "Revision of Acroleptus Bourgeois, 1886 and Descriptions of New Acroleptina Taxa (Coleoptera, Lycidae, Calopterini).” Journal of Natural History 53, no. 45-46 (December 10, 2019): 2739-2756. doi:10.1080/00222933.2020.1733120. 


\title{
Revision of Acroleptus Bourgeois, 1886 and Descriptions of New Acroleptina taxa (Coleoptera, Lycidae, Calopterini)
}

\author{
VINICIUS S. FERREIRA \\ Montana Entomology Collection \\ Marsh Labs, Room 50 \\ Montana State University \\ Bozeman, MT 59717, USA \\ vinicius.sfb@gmail.com
}

\begin{abstract}
The Neotropical lycid genus Acroleptus Bourgeois, 1886 is revised and illustrations of diagnostic characters, geographic distribution maps and an identification key to the species are presented. Acroleptus chevrolati Bourgeois, 1886 is redescribed and a lectotype and a paralectotype are designated; two new species are described for the genus: Acroleptus alvarengai new species and Acroleptus limai new species. Two Aporrhipis Pascoe, 1887 species are described: Aporrhipis obrieni new species and Aporrhipis milleri new species and a key and geographic distribution map to the species of the genus are provided. Acroleptus costae Ferreira, 2015 is moved to the genus Paracroleptus new genus, a new genus erected to accommodate Paracroleptus costae (Ferreira, 2015) new combination.
\end{abstract}

Key words: Leptolycini, Neotropical Region, Neoteny, Elateroidea, Paedomorphosis.

\section{Introduction}

Acroleptus Bourgeois, 1886 is a small genus of Lycidae currently comprised of two species, Acroleptus chevrolati Bourgeois, 1886 and Acroleptus costae Ferreira, 2015. Both species are endemic to Brazil and only known by the three specimens belonging to their respective type series (Bourgeois 1886; Ferreira 2015). Acroleptus was redescribed by Bocakova (2003) in her revisionary work of the tribe Calopterini and incorporated in a phylogenetic study proposed in 2005 , where the genus was found to be closely related to Lycomorphon Pic, 1922 Ceratopriomorphus Pic, 1922 and Lycinella Gorham, 1884. 
The group formed a monophyletic group in the tribe Calopterini and Bocakova (2005) erected the subtribe Acroleptina to accommodate the clade.

The taxonomy of the subtribe is well studied compared to other Neotropical Lycidae, with all genera but Acroleptus being revised in the last 10 years (e.g. Ferreira and Ivie 2018 revision of the genus Lycinella). The relatively well resolved taxonomy of the group allowed the tentative placement of the genus Aporrhipis Pascoe, 1887 in the subtribe Acroleptina by Ferreira et al. (2018).

During the extensive process of receiving loans of lycid beetles for my $\mathrm{PhD}$ research, I found Acroleptus and Aporrhipis specimens among the unidentified material sent to me from over 20 scientific collections. A careful examination of that material indicated that most specimens were, in fact, undescribed species. In this study I take the opportunity to rediagnose and redescribe the genus Acroleptus, describe two new species, and provide illustrations of diagnostic characters, distribution maps and a key to all species. Two new species of Aporrhipis are described and a key to the species within the genus is provided.

\section{Material and methods}

Specimens were studied under a Leica ${ }^{\circledR}$ Wild M3C stereoscopic microscope with magnification up to 40x. Photos were taken using a JVC (DC Ky-F75U) digital camera mounted on a Leica ${ }^{\circledR}$ MS5 stereoscope and a Canon T3i DSLR with lenses MP-E 65 mm using a Stackshot ${ }^{\mathrm{TM}}$ - automated macro rail for focus stacking. Images were stacked using the software Zerene Stacker® software version 1.04. Enhancements to digital images were made in Adobe Photoshop® CC 2019. Drawings were prepared based on photographs using the Adobe Illustrator ${ }^{\circledR}$ CC 2019. The distribution map technique follows Ferreira (2016): the map was generated using the software Google Earth and Quantum GIS 3.6.1, using the maps available in the website http://www.naturalearthdata.com, a free public database of maps.

Morphological terminology follows Crowson (1944), Bocak and Bocakova (1990), Kazantsev (2003) and Lawrence et al. (2011). Male genitalia were dissected after the entire specimen was soaked in hot water. For disarticulation and clearing processes the specimens were left overnight in a solution of $\mathrm{KOH}$ after which they were dissected; a drop of vinegar 
was added at the end of the process to stop the $\mathrm{KOH}$ reaction. Transcription of label data from specimens follows Ivie (1985): the end of each line on a label is indicated by a ";" (semicolon); the individual labels are separated by a “"” (slash). Material examined is deposited in the following collections (respective curators are indicated in parentheses):

CNC - Canadian National Collection of Insects, Ontario, Ottawa, Canada (Hume Douglas and Patrice Bouchard)

FSCA - Florida State Collection of Arthropods, Gainesville, Florida, USA (Paul Skelley).

MNHN - Muséum national d'Histoire naturelle, Paris, France (Antoine Mantilleri).

NMNH - The Natural History Museum, London, London, United Kingdom (Maxwell V. L. Barclay and Michael Geiser).

RBINS - Royal Belgian Institute of Natural Sciences, Brussels, Belgium (Pol Limbourg).

USGA - University of Georgia Collection of Arthropods, Athens, Georgia, USA (Joseph V. McHugh)

\section{Results}

\section{Revision of Acroleptus}

Family Lycidae Laporte, 1836

Subfamily Lycinae Laporte, 1836

Tribe Calopterini Green, 1949

Subtribe Acroleptina Bocakova, 2005

Genus Acroleptus Bourgeois, 1886

Figs. 1-18, 25.

Acroleptus Bourgeois, 1886: LXX; Kleine 1933: 34; Blackwelder 1945: 348; Bocakova 2003: 215, 231; Bocakova 2005: 445; Bocak and Bocakova 2008: 713; Ferreira 2015: 297. 
Acroleptus; Cabanis 1861: 90; Gray 1870:78, McGregor 1920:8, Hellmayr 1936: 14 (see remark below).

Type species. Acroleptus chevrolati Bourgeois, 1886 (by monotypy).

Differential diagnosis. Acroleptus can be distinguished from other Calopterini by the combination of pronotum with a strongly visible longitudinal cell (Figs. 1, 4, 7) (vs. absence or weakly developed cell in Aporrhipis), flabellate antennae with flabellum of antennomere III subequal in length with the stem (Figs. 10, 11) (vs. serrate or subserrate in most genera, except Aporrhipis), frons concave and elongate (Figs. 3, 6, 9) (vs. transverse frons in Aporrhipis), elytra with four costae, easily visible and reticulate (Figs. 1, 4, 7) (vs. costae indistinct and incomplete with weak reticulation in Aporrhipis), non-reduced mouthparts and male genitalia with the presence of folds in the basal inner margin of median lobe (Figs. 16-18).

Description. General dorsal coloration dark brown, with pronotum dark brown or orange (Fig. 1, 4, 7). Body setose, dorsal pubescence long and erect on elytra, remainder of body with fine yellowish pubescence throughout (Figs. 1-9).

Body. Head: as long as wide, widest behind eyes, posteriorly partially covered by pronotum, hypognathous, frons concave and elongate, acuminate at apex (Fig. 3, 6, 9). Eyes hemispherical, projecting anterolaterally when viewed dorsally; coarsely granulate.

Mouthparts: Maxillary palp four-segmented, with last palpomere acuminate, setose. Labial palp 3-segmented, terminal segment, acuminate, setose. Mandibles strongly hooked apically. Posterior margin of epistoma emarginate, labrum transverse, setose. Antennae: inserted in gibbous prominence at anterior portion of head, 11-segmented (Fig. 10, 11), reaching middle of elytra or apex, densely setose; scape subconic, pedicel short, flagellomeres III-X flabellate on outer portion; flabellum of antennomere III subequal in length with the stem (Fig. 10, 11).

Prothorax: Pronotum transverse, trapezoidal; margins prominent; anterior angles round, posterior angles moderately acute; longitudinal carina present in anterior portion, bifurcated medially forming a cell (Figs. 1, 4, 7). Hypomeron concave, when viewed laterally, basal margin ranging from emarginate to marginate. Prosternum Y-shaped, tripartite, connected to hypomeron by additional segment (Fig. 12). Mesothorax: Mesoespiracles short, slightly protuberant (Fig. 12). Mesoventrite trapezoidal, posteriorly 
reaching anterior margin of metaventrite, connected to mesanepisternum by additional segment, mesepimeron more densely pubescent than surrounding sclerites (Fig. 12). Scutellum protruded, posteriorly bifurcated. Metathorax: Metaventrite convex, posterolateral angles pronounced, acute; metadiscrimen complete; metanepisternum and metepimeron elongate, widest in the middle, metendosternite (as represented by Acroleptus alvarengai) elongate, membranous, with strongly visible ventral longitudinal flange, furcal arms short and not protrudent (Fig. 14). Elytra: subparallel, ranging from 7 to $8 \times$ longer than pronotum; reticulate, with four elytral costae more or less developed on each elytron, secondary costae absent (Figs. 1, 4, 7). Legs: slender, elongate; Protrochanthin slender and exposed (Fig. 12); trochanters tubular; femora and tibiae quite elongate, ranging from clavate to subparallel, subequal in length (Fig. 13); Pro- and mesocoxae conical, obliquely positioned, procoxae contiguous, metacoxae transverse (Fig. 12); tarsomeres 5-5-5, very narrow, tarsomere four not expanded laterally (Fig. 13).

Abdomen of males with eight ventrites, tapered towards apex, densely setose (Fig. 15); male genitalia symmetrical; median lobe ranging from twice to $2 / 3$ the length of parameres, slightly tapered towards apex, rounded apically, with the presence of folds in the basal inner margin of median lobe (Figs. 16-18); parameres rounded apically; phallobase elongate, lateral margins subparallel, posterior margin rounded or irregular (Figs. 16-18).

Females unknown.

Length (pronotum+elytra): 4.6-5.2 $\mathrm{mm}$. Width (across humerus): $1.1-1.4 \mathrm{~mm}$.

Distribution. Acroleptus is known only to occur in Brazil but expected to be found in other surrounding South American countries (Fig. 25).

Biology and immature. Females are unknown and presumably neotenic (see discussion section). As for many other Neotropical lycids, information about the ecology and biology of Acroleptus is unknown.

Remark. See Ferreira (2015) for a discussion on the validity of Acroleptus Bourgeois, 1886 (Insecta) over Acroleptus Cabanis, 1861 (Aves), the latter being an incorrect subsequent spelling.

\section{Key to the species of Acroleptus}


1. Pronotum unicolored, orange (Fig. 7); folds in the basal inner margin of median lobe strongly developed (Fig.18). Acroleptus limai new species 1'. Pronotum bicolored, either with margins or disc region orange or yellow (Figs. 1, 4) genitalia variable .2

2. Pronotum orange, disc region dark brown (Fig. 4); elytra completely dark brown (Fig. 4); median suture of phallobase absent (Fig. 17). Acroleptus alvarengai new species 2'. Pronotum dark brown, lateral margins yellow (Fig. 1); humeral region of elytra yellow (Fig. 1); median suture of phallobase present (Fig. 16). Acroleptus chevrolati Bourgeois, 1887

\section{Acroleptus chevrolati Bourgeois, 1886}

Figs. 1-3, 16, 25.

Acroleptus chevrolati Bourgeois, 1886: LXX; Kleine 1933: 34; Blackwelder 1945: 348; Bocakova 2003: 231 figs. 20, 37, 72, 73, 114-116.

Type material examined (2). Lectotype and paralectotype (hereby designated to preserve stability of nomenclature, in accordance with ICZN (1999) Art. 74.7). 1 ๙ Lectotype: Coll. R. I. Sc. N. B.; Brazil; Coll. Guér-Mén./ n. g.; chevrolati; Guer/ Lycus; gns 13/ Acroleptus; chevrolati Brg 1885; det. Bourgeois/ Type/ LECTOTYPE; Acroleptus chevrolati Bourgeois, 1886; det V.S. Ferreira 2019 (IRSB). $1 \overbrace{}^{\Uparrow}$ Paralectotype: Coll. R. I. Sc. N. B.; Brazil; Coll. Guér-Mén.; Rio Janeiro, 8.12; Coll. Camille; Van Voixem./ Acroleptus; chevrolati; MALE SYMBOL Bourg.; 1886/ Type/ PARALECTOTYPE; Acroleptus chevrolati Bourgeois, 1886; det V.S. Ferreira 2019 (IRSB). Material examined in addition to type (2). $1 \delta^{-}$: MUSEUM PARIS; MINAS GERAES; CLAUSSEN 9-43/ 9 43/ Acroleptus chevrolati + Bourg (MNHN). 10 ${ }^{\lambda}$ : Rio de Janeiro; Organ Mts.; near Tijuca; S.R. Wagner.; 1902-287/ Determined from; description C.J.G.; Acroleptus; chevrolati; Bourg. (BMNH).

Diagnosis. The pronotum and humeral lateral margins yellow (Fig. 1), elytral cells subquadrate (Fig. 2) and the phallobase of male genitalia with median suture incomplete, 
present only in apical half, distinguishes (Fig. 16) A. chevrolati from other members of the genus.

Redescription. Head dark brown (Fig. 3). Antennae reaching middle of elytra, densely setose; flabellum of antennomere III and IV subequal in length with their respective stems; flabellum of antennomere V-X about 2.5x longer than stem. Pronotum dark brown, lateral margins yellow (Fig. 1, 2). Elytra: dark brown, except by humeral region yellow, subparallel, 7x longer than pronotum; reticulate, cells subquadrate, with four elytral costae reaching apex of elytra (Figs. 1). Male genitalia bilaterally symmetrical; exposed portion of median lobe twice the length of parameres, slightly tapered towards apex, rounded apically, with a membranous round structure in the apex of median lobe; folds in the basal inner margin of median lobe weakly developed; phallobase elongate, lateral margins subparallel, posterior margin round, with median suture incomplete, present only in apical half (Figs. 16).

Length (pronotum+elytra): 4.6-5.2 mm. Width (across humerus): $1.1-1.4 \mathrm{~mm}$.

Distribution. Rio de Janeiro and Minas Gerais, Brazil (Fig. 25).

Type locality. Rio de Janeiro, Brazil.

Remarks. The label of the MNHN specimen indicates that the specimen is a female. The specimen has been already dissected and examined by someone else before this study, and the terminalia is missing from the specimen. Examination of other external morphological characters do not support that this specimen is a female.

\section{Acroleptus alvarengai Ferreira new species}

Figs. 4-6, 17, 25.

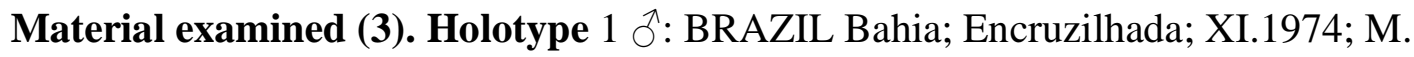
Alvarenga (CNC). Paratypes, $2 \widehat{\delta}$ : Same data as holotype.

Etymology. The species was named after Moacyr Alvarenga. He was a lieutenant of the Brazilian air force (Teixeira de Freitas 1956) and a very prolific collector of insects and other animals in Brazil.

Diagnosis. The pronotum yellow with disc region dark brown, the elytra completely dark brown bearing irregular rectangular cells (Fig. 4) and the male genitalia shape (Fig. 17) distinguishes A. alvarengai from other species in the genus. 
Description. Head dark brown (Fig. 6). Antennae reaching middle of elytra, densely setose; flabellum of antennomere IV twice the length of stem; flabellum antennomere $\mathrm{V} 3 \mathrm{x}$ longer than stem; flabellum of antennomeres VI and VII 4.5x longer than stem; flabellum of antennomeres VII and IX 5x longer than stem; flabellum of antennomere X 4x longer than stem. Pronotum yellow, disc region dark-brown. Elytra: dark brown, subparallel, 7x longer than pronotum; reticulate, irregular rectangular cells, with four elytral costae; costa I only reaching 3/4 of elytra length (Figs. 4, 5). Male genitalia bilaterally symmetrical; exposed portion of median lobe $1.5 \mathrm{x}$ the length of parameres, slightly tapered towards apex, rounded apically, with a membranous round structure in the apex of median lobe; folds in the basal inner margin of median lobe strongly developed; phallobase elongate, lateral margins subparallel, posterior margin round, median suture absent (Fig. 17).

Length (pronotum+elytra): $4.5-4.7 \mathrm{~mm}$. Width (across humerus): $1.1-1.2 \mathrm{~mm}$.

Distribution. Bahia, Brazil (Fig. 25).

Type locality. Encruzilhada, Bahia, Brazil.

\section{Acroleptus limai Ferreira new species}

Figs. 7-9, 18, 25.

Material examined (1). Holotype 1 : Espirito Santo/ Descowtils/ 6524/ Fry coll; 1905-100 (NMNH).

Etymology. The species is named after Rodrigo Lima, born and raised in Vitória, Espírito Santo, and the lead singer and lyricist for the hardcore punk band Dead Fish.

Diagnosis. The pronotum and the sides of head yellow (Figs. 7-9), the irregular cells on elytra and the male genitalia distinguishes (Fig. 18) A. limai from other members of the genus.

Description. Head dark brown, sides yellow (Figs. 7, 9). Antennae reaching middle of elytra, densely setose; flabellum of antennomere III and IV subequal in length with their respective stems; flabellum of antennomere $\mathrm{V}$ about 1.5x longer than stem; flabellum of antennomeres VI twice the length of stem; flabella of antennomeres VII-X 3x longer than respective stems. Elytra: subparallel, 7x longer than pronotum; reticulate, cells irregular, with four elytral costae reaching apex of elytra (Figs. 7, 8). Male genitalia bilaterally symmetrical; exposed portion of median lobe twice the length of parameres, slightly 
tapered towards apex, rounded apically, with a membranous round structure in the apex of median lobe; folds in the basal inner margin of median lobe strongly developed; phallobase elongate, lateral margins subparallel, posterior margin round, with median suture absent (Figs. 18).

Length (pronotum+elytra): $5.0 \mathrm{~mm}$. Width (across humerus): $1.2 \mathrm{~mm}$.

Distribution. Espírito Santo, Brazil (Fig. 25).

Type locality. Espírito Santo, Brazil.

\section{Species removed from Acroleptus}

\section{Paracroleptus Ferreira, 2019 new genus}

Type species. Acroleptus costae Ferreira, 2015, herein designated.

Description. A comprehensive examination of Acroleptus and Aporrhipis types indicated that Acroleptus costae Ferreira, 2015 does not belong to any of these genera nor any already described genus, and Paracroleptus new genus is hereby erected to accommodate this species (See description in Ferreira 2015: 298). Paracroleptus can be separated from both genera by the dehiscent elytra (vs. subparallel in Aporrhipis and Acroleptus), reduced mouthparts (vs. non-reduced mouthparts in Aporrhipis and Acroleptus) and by the parameres free, not co-opted with median lobe (vs. completely or partially fused parameres, co-opted with median lobe). The genus is provisionally placed in the Acroleptina based on the folds in the basal inner margin of median lobe, shared with Acroleptus, Aporrhipis and Ceratopriomorphus Pic, 1922.

\section{Paracroleptus costae (Ferreira, 2015) new combination}

Acroleptus costae Ferreira, 2015: 298, figs. 1-4.

Type locality. Brazil, Rondônia State, Porto Velho. Distribution. Brazil.

\section{Aporrhipis new species descriptions}

Family Lycidae Laporte, 1836

Subfamily Lycinae Laporte, 1836

Tribe Calopterini Green, 1949 


\section{Subtribe Acroleptina Bocakova, 2005}

Aporrhipis Bourgeois, 1887

Aporrhipis Pascoe 1887: 18; Csiki 1913: 25; Crowson 1972: 48; Bocak and Bocakova 1990: 628; Miller 1991: 311; Kaupp et al. 2001: 174; Falin 2003: 228; Batelka and Hajek 2009: 777. Ferreira et al. 2018: 372.

Type species. Aporrhipis flexilis Pascoe, 1887:18, by monotypy.

Updated diagnosis. Aporrhipis can be separated from other Calopterini by the combination of pronotum bearing a weakly developed longitudinal carina or cell or absent cell, flabellate antennae, concave and transverse frons, elytra with four costae, sometimes indistinct and weakly reticulated, non-reduced mouthparts and male genitalia with the presence of folds in the basal inner margin of median lobe (see detailed redescription in Ferreira et al. 2018).

\section{Key to the species of Aporrhipis}

1. Body unicolored, dark brown; exposed portion of median lobe elongate, twice as long as parameres (Fig. 5, 6 in Ferreira et al. 2018). Aporrhipis flexilis Pascoe, 1887

1'. Body bicolored; exposed portion of median lobe subequal in length with parameres.....2 2. Pronotum with a longitudinal carina easily visible, cell absent (Fig. 19); folds in the basal inner margin of median lobe strongly developed, half the length of exposed portion of median lobe (Fig. 23) Aporrhipis obrieni Ferreira new species 2.' Pronotum with a weakly visible cell in posterior portion (Fig. 22); folds in the basal inner margin of median lobe, only present in basal third of exposed portion of median lobe (Fig. 24). Aporrhipis milleri Ferreira new species

\section{Aporrhipis obrieni Ferreira new species}

Figs. 19-21, 23, 25

Material examined (4). Holotype 1 $\delta^{\lambda}$ : BRAZIL Rondonia; $62 \mathrm{Km}$. SW.Arique;mes, Fzda. Rancho; Grande. X-8-1993/ Collectors: C.W. \& L.B. O'Brien (FSCA). Paratypes 10: BRAZIL Rondonia; 6 2Km. SW.Arique-;mes, Fzda. Rancho; Grande. X- 
11-1993/ Collectors: C.W. \& L.B. O'Brien (FSCA). 2今̊: BRAZIL Rondonia; 64km SE Ariquemes; 1-14 Nov. 1997; B. Dozier (USGA).

Etymology. This species is named in honor of Charles W. and Lois B. O'Brien, collectors of the type series of this species.

Diagnosis. The bicolored body, the presence of a longitudinal carina on pronotum (Fig. 19) and the male genitalia (Fig. 23) helps to distinguish Aporrhipis obrieni from other species in the genus.

Description. General color dark brown (Fig. 19); head, scape, pedicel, base of antennomere III, humeral region and legs yellow (Fig. 19, 21). Antennae reaching apex of elytra, densely setose; flabellum of antennomere III subequal in length stem; flabellum of antennomere IV 1.5x longer than stem; flabellum of antennomere $\mathrm{V}$ about $2 \mathrm{x}$ longer than stem; flabella of antennomeres VI-X about 4x longer than respective stem. Pronotum bearing a longitudinal carina (Fig. 19). Elytra: subparallel, 8x longer than pronotum; reticulation vestigial and hardly identifiable, with four elytral costae, costae I and II weakly developed, no reaching apex of elytra; costa III and IV reaching apex of elytra, connected at apex. Legs: slender, elongate; trochanters tubular; femora and tibiae elongate, femora subparallel, tibiae clavate. Male genitalia bilaterally symmetrical; exposed portion of median lobe subequal in length of parameres, slightly expanded towards apex, rounded apically; folds in the basal inner margin of median lobe strongly developed, half the length of exposed portion of median lobe, membranous, with apices acuminate; apices of parameres hooked; phallobase subequal in length with parameres, lateral margins subparallel, posterior margin round, with median suture absent (Fig. 23).

Length (pronotum+elytra): $3.1-3.3 \mathrm{~mm}$. Width (across humerus): $1.1-1.2 \mathrm{~mm}$.

Distribution. Rondônia, Brazil (Fig. 25).

Type locality. Ariquemes, Rondônia, Brazil.

\section{Aporrhipis milleri Ferreira new species}

Figs. 22, 24, 25.

Material examined (1). Holotype $1 \delta^{\lambda}$ : BRASIL: Para; nr. Maraba, nr.; Bacuri; 24X-1974; J.F. Reinert; malaise trap (FSCA). 
Etymology. This species is named in honor of the great North American Lycidae systematist, Richard Stuart Miller.

Diagnosis. The bicolored body, the presence of a weakly developed cell in posterior portion of pronotum (Fig. 22) and the male genitalia (Fig. 25) helps to distinguish Aporrhipis milleri from other species in the genus.

Description. General color dark brown; head, scape, pedicel, humeral region and base of femora and tibiae yellow. Antennae reaching subapex of elytra, densely setose; flabellum of antennomere III twice the length of stem; flabellum of antennomere IV and V $2.5 \mathrm{x}$ longer than stem; flabellum of antennomere VI about $4 \mathrm{x}$ longer than stem; flabellum of antennomere VII about 3x longer than stem; flabella of antennomeres VIII-X about 2.5x longer than respective stem. Elytra: subparallel, 8x longer than pronotum; reticulation vestigial and hardly identifiable, with four elytral costae. Legs: slender, elongate; trochanters tubular; femora and tibiae elongate, femora subparallel, tibiae clavate. Male genitalia bilaterally symmetrical; exposed portion of median lobe subequal in length of parameres, rounded apically; folds in the basal inner margin of median lobe strongly developed, only present in basal third of exposed portion of median lobe, membranous, with apices acuminate; apices of parameres hooked; phallobase elongate, $1.5 \mathrm{x}$ longer than parameres, lateral margins subparallel, posterior margin round, median suture absent (Figs. 24).

Length (pronotum+elytra): $4.5 \mathrm{~mm}$. Width (across humerus): $1.3 \mathrm{~mm}$.

Distribution. Pará, Brazil (Fig. 25).

Type locality. Marabá, Pará, Brazil.

\section{Discussion}

The subtribe Acroleptina (Calopterini), where Acroleptus and Aporrhipis are currently placed, is suspected of having paedomorphic females (Barancikova et al. 2010; Ferreira and Ivie 2008; Ferreira et al. 2018), as do the known Leptolycini (Miller 1991, Kazantsev 2013). Acroleptus and Aporrhipis conform with the biology habits and general morphology of the groups with known or suspected paedormophic females: specimens are rarely collected, and have an apparent preponderance to be caught in FITs and Malaise traps, elytra are usually less sclerotized and weakly developed and reticulate (e.g. when 
compared to other non-paedomorphic Neotropical lycids, such as Calopteron, Mesopteron or Metapteron and Falsocaenia), their antennae are inserted in a gibbous prominence at the anterior portion of the head, membranous wings are weakly developed and have less veins and females are unknown, even in large series (e.g. Lycinella parvula Gorham, 1884 in Ferreira and Ivie 2008).

With the exception of Lycinella, all other Acroleptina lycids are known by few specimens in small series, of which most specimens were presumably collected with nets, without the use of specialized traps. The lack of specialized collecting techniques allied with a poor and restricted sampling area - and in the case of Brazilian lycid fauna, most collections are done in coastal areas or in specific field stations - leave huge gaps of unsampled areas, as seen in figure 25, for example. To test the hypothesis that Acroleptina and even other lycid groups that are suspected of having paedomorphic females have in fact paedomorphic females, the implementation of specialized collecting techniques, such as FITs and Malaise for winged insects and the use of pitfalls, leaf-litter sifting, Winklers, Berlese's and soil washing for wingless insects, would bring light to this unanswered question and finally clarify this mystery, and collaterally increase the diversity of specimens and species collected with the use of specialized techniques.

\section{Acknowledgments}

Richard S. Miller's generous donation of his collection to the Montana Entomology Collection (MTEC) was critical to this project. I am very thankful to Erich L. Spiessberger (MTEC) and Oliver Keller (University of Florida) for comments and advice during the development of this study and for their comments pre-submission; I am grateful to the respective curators and collections managers of each collection who provided material for this study. VSF is very grateful to Conselho Nacional de Desenvolvimento Cientifico e Tecnológico (CNPq) of Brazil for the scholarship (process 202559/2015-7) that allowed him to continue his study of the Lycidae and to the Idea Wild Project for providing resources that allowed the acquisition of the photographic equipment used in this project. This is a contribution of the Montana Agricultural Experiment Station.

\section{Reference}


Blackwelder, R. E. 1945. Checklist of the coleopterous insects of Mexico, Central America, the West Indies and South America. Bulletin of the United States National Museum 185(1-6): 1-925.

Bocak, L. and Bocakova, M. 1990. Revision of the suprageneric classification of the family Lycidae (Coleoptera). Polskie Pismo Entomologiczne 59: 623-676.

Bocakova, M. 2003. Revision of the tribe Calopterini (Coleoptera, Lycidae). Studies on Neotropical Fauna and Environment 38: 207-234.

Bocakova, M. 2005. Phylogeny and classification of the tribe Calopterini (Coleoptera, Lycidae). Insect Systematics and Evolution 35: 437-447.

Bourgeois, J. 1891. Études sur la Distribution géographique des Malacodermes. I. Lycides. Annales de la Société entomologique de France LX: 337-364 + 1 map.

Cabanis, J. 1861. Uebersicht der im Berliner Museum befindlichen Vögel von Costa Rica. Journal für Ornithologie, 50, 81-96.

Crowson, R. A. 1944. Further studies on the metendosternite in Coleoptera. Transactions of the Royal Entomological Society of London 94: 273-310.

Ferreira, V. S. 2016. A revision of the genus Macrolygistopterus Pic, 1929 (Coleoptera, Lycidae, Calochromini). Zootaxa 4105: 321-338.

Ferreira, V. S., Barclay, M. V. L. and Ivie, M. A. 2018. Redescription of Aporrhipis Pascoe, 1887 (Coleoptera: Lycidae), with a discussion of its tribal placement. The Coleopterists Bulletin 72(2): 371-375. 
Ferreira, V.S. 2015. A new species of Acroleptus Bourgeois (Coleoptera: Lycidae) from the Brazilian Amazonian rainforest, with a note on its homonymy with Acroleptus Cabanis (Aves). Zootaxa 3949(2): 297-300.

Ferreira, V.S. and Ivie, M.A. 2018. A revision of Lycinella Gorham, 1884 with the description of six new species (Coleoptera, Lycidae, Calopterini). ZooKeys 792: 69 $-89$.

Gray, G.R. 1870. Hand-list of genera and species of birds, distinguishing those contained in the British Museum. Part 2. Conirostres, Scansores, Columbae \& Gallinae. Trustees of the British Museum, London, 278 pp.

Green, J.W. 1949. The Lycidae of the United States and Canada. I. The tribe Lycini (Coleoptera). Transactions of the American Entomological Society 75 (2): 53-70.

Hellmayr, C.E. 1936. Catalogue of birds of the Americas and the adjacent islands in Field Museum of Natural History, part IX, Tersinidae, Thraupidae. Field Museum of Natural History Publications, Zoological Series 13: 1-458.

ICZN [International Commission on Zoological Nomenclature]. 1999. International code of zoological nomenclature. Fourth Edition. London: The International Trust for Zoological Nomenclature.

Ivie, M. A. 1985. Nomenclatural notes on West Indian Elaphidiini (Coleoptera: Cerambycidae). Pan-Pacific Entomologist 61(4): 303-314.

Kazantsev, S.V. 2003. Morphology of Lycidae with some considerations on evolution of the Coleoptera. Elytron 17: 49-226.

Kazantsev, S.V. 2013. New and little-known taxa of "neotenic" Lycidae (Coleoptera), with discussion of their phylogeny. Russian Entomological Journal 22: 9-31. 
Kleine, R. 1933. Lycidae Pars 128. In: Junk W, Schenkling S. (Eds.). Coleopterorum Catalogueus auspiciis et auxilio, Berlin, $145 \mathrm{pp}$.

Laporte [=Castelnau] FLNC, de .1836. Études entomologiques, ou descriptions d'insectes nouveaux et observations sur la synonymie [continued]. Revue Entomologique 4: 5-60, table. [1836 (title page); 7 Feb 1838 (Ann. Soc. Ent. France 7: Bull. Ent.: iv)]

Lawrence, J.F., Slipinski, A., Seago, A. E., Thayer, M.K., Newton, A.F. and Marvaldi, A.E. 2011. Phylogeny of the Coleoptera based on morphological characters of adults and larvae. Annales Zoologici 61: 1-217.

McGregor, R.C. 1920. Index to the genera of birds. Manila Bureau of Printing, 185 pp.

Teixeira de Freitas, J. F. 1956. Sôbre os gêneros Thelandros Wedle, 1862 e Parapharyngodon Chatterji, 1933, com descrição de Parapharyngodon alvarengai sp. n. (Nematoda, Oxyuroidea). Memórias do Instituto Oswaldo Cruz 55: 021-053.

\section{Figure Captions}

Plate 1. Figures 1-3. Acroleptus chevrolati Bourgeois, 1886. 1. Dorsal habitus. 2. Ventral habitus. 3. Frons. Scale bars: $1 \mathrm{~mm}$.

Plate 2. Figures 4-6. Acroleptus alvarengai new species. 4. Dorsal habitus. 5. Ventral habitus. 6. Frons. Scale bars: $1 \mathrm{~mm}$. 
Plate 3. Figures 7-9. Acroleptus limai new species. 7. Dorsal habitus. 8. Ventral habitus. 9. Frons. Scale bars: $1 \mathrm{~mm}$.

Plate 4. Figures 10-15. Acroleptus alvarengai morphology. 10. Head, dorsal view. 11. Antenna. 12. Thorax, ventral view. 13. Pro-leg. 14. Metendosternite. 15. Abdomen. Scale bars: $1 \mathrm{~mm}$, unless otherwise stated.

Plate 5. Figures 16-18. Acroleptus male genitalia, ventral and dorsal view. 16. Acroleptus chevrolati. 17. Acroleptus alvarengai. 18. Acroleptus limai. Scale bars: $0.5 \mathrm{~mm}$.

Plate 6. Figures 19-21. Aporrhipis obrieni. 19. Dorsal habitus. 20. Ventral habitus. 21. Frons. Scale bars: $1 \mathrm{~mm}$.

Plate 7. Figures 22-24. 22. Aporrhipis milleri, dorsal habitus. Scale bar: $1 \mathrm{~mm}$. 23. A. obrieni male genitalia, ventral and dorsal view. 24. A. milleri male genitalia, ventral and dorsal view. Scale bars: $0.5 \mathrm{~mm}$.

Plate 8. Figure 25. 25. Distribution map of Acroleptus and Aporrhipis species. 